ефективних методів та прийомів для успішного засвоєння необхідних знань, умінь i навичок ведення здорового способу життя; організація індивідуалізованого навчання (робота у групах, індивідуальна робота); організації самонавчання, зокрема підготовка студентів до збереження і зміцнення здоров'я та ведення здорового способу життя.

Російський педагог Р. Раевський, розглядаючи роль викладача в роботі зі студентами, спрямованої на забезпечення потреби студентів у здоровому способі життя, визначає такі функції викладання: 1) аналітико-прогностичну (визначає необхідний обсяг валеологічних знань); 2) проектну (вибір змісту навчання: аудиторні заняття, виконання письмових робіт, виконання різних дослідницьких робіт, самостійне вивчення теми); 3) комунікативну (мотивує, інформує, керує діяльністю студента під час дотримання здорового способу життя); 4) дидактичну (створює необхідний дидактичний матеріал, рекомендації щодо його виконання); 5) контрольно-корегувальну (контроль і корекція рівня знань); 6) психологічної підтримки (консультування, групові тренінги); 7) організаторську (оздоровча робота та робота в таборах) [5, с. 435].

Отже, щоб мати здорове покоління, необхідно ширше та глибше розвивати роботу серед молоді, пов'язану з забезпеченням потреби у здоровому способі життя. Провідна роль у цій роботі належить педагогу, який мотивує, організовує, корегує, пропагує та формує у студентів навички здорового способу життя.

Зважаючи на актуальність проблеми та необхідність їі детального вивчення, у подальшому перспективним уважаємо вивчення шляхів ініціації органами державної влади та місцевого самоврядування різноманітних проектів, спрямованих на поширення здорового способу життя серед молоді.

\title{
Література
}

1. Біда О. А. Збереження і зміцнення здоров'я студентської молоді в освітньому процесі / О. А. Біда // Вісник Черкаського ун-ту. Серія: Педагогічні науки. - Черкаси, 2012. - № 24 (237). - С. 12-15. 2. Борисов Б. А. Организация и методика проведения практических занятий в вузе по учебной дисциплине «Физическая культура» : [учеб. пособие] / Б. А. Борисов. - Кемерово, 2005. - 453 с. 3. Вольнская Е. В. Воспитание культуры здоровья в профессиональной подготовке студентов педагогического вуза : автореф. дис. на соискание учен. степени канд. пед. наук: спец. 13.00.08 «Теория и методика профессионального образования»/ Е. В. Вольнская. - Тула, 2009. - 22 с. 4. Краснов И. С. Методологические аспекты здорового образа жизни россиян / И.С. Краснов// Физическая культура: воспитание, образование, тренировка. - 2004. - № 2. - С. 61-63. 5. Раевский Р. Т. Здоровье, здоровый и оздоровительный образ жизни студентов / Р. Т. Раевский, С. М. Канишевский; под общ. ред. Р. Т. Раевского. - Одесса : Наука и техника, 2008. - 556 c.

УДК: 005:008: 316

Світлана Яиник

\section{АНТРОПОЛОГІЧНИЙ ПІДХІД ДО УПРАВЛІНСЬКОЇ КУЛЬТУРИ ФАХІВЦІВ СІЛЬСЬКОГОСПОДАРСЬКОЇ ГАЛУЗІ}

Яшник С. В. Антропологічний підхід до управлінської культури фахівців сільськогосподарської галузі.

Аналізується категорія ментальності в аспекті виявлення глибинних феноменів психіки етносів, які регулюють поведінку і спосіб буття особистості у світі. 
Характеризується видова ментальність та звертається увага на необхідності врахування менталітету у формуванні управлінської культури.

Ключові слова: антропологічний підхід, ментальність, етнічна культура, управлінська культура.

Яшник С. В. Антропологический подход к управленческой культуре специалистов сельскохозяйственной отрасли.

Анализируется категория ментальности в плане выявления глубинных феноменов психики, которые регулируют поведение и способ бытия личности в мире. Характеризуется видовая ментальность и обращается внимание на необходимость учета менталитета в формировании управленческой культуры.

Ключевые слова: антропологический подход, ментальность, этническая культура, управленческая культура.

Yashnik S. V. Anthropological approach to the management culture of the agricultural sector professionals.

Category of mentality is analyzed I case of lighting the cover psychic deviations, that regulated one's behavior and style of leaving individual in the world. Mentality is characterizing and makes point on need of mentality in development of management culture.

Key words: anthropological method, mentality, ethnic culture, management culture.

Суспільно-економічний розвиток України потребує не тільки збереження незалежності як умови створення національної економіки, але й сприяння національній культурі, що складає його духовну основу. Розвиток культури узгоджується із поступом економіки. Задля цього необхідно подолати відірваність

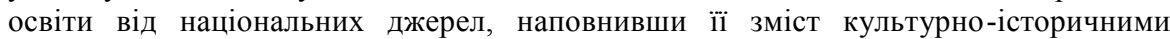
надбаннями, утвердженням людини як найвищої соціальної цінності, гармонії іiі стосунків 3 навколишнім середовищем, суспільством і природою. Управлінська культура має бути не тільки зорієнтованою на переосмислення складних реалій соціоприродної дійсності як умови створення національної економіки, але й на сприяння відродженню національної культури.

Нині з проблем дослідження українського менталітету, його еволюції та зв'язку 3 народною культурою, поведінкою, традиціями i звичаями, які дають можливість прослідкувати специфіку глибинних психологічних рис етносу, є багато розвідок науковців (О. Апанович, В. Борейко, О. Воропай, О. Губко, М. Гримич, О. Ковальов, В. Крисаченко, А. Кульчицький, Ю. Липа, Б. Мірчук, Ю. Присяжнюк, С. Рудницький, В. Скуратівський, А. Стражний, А. Фурман, В. Янів, Я. Ярема та ін); плідно висвітлюється питання видової ментальності: ментальний чинник у сфері праці (Д. Богиня, І. Курас, В. Попов, М. Семикіна); уплив несвідомого на професійні цінності (М. Іванов, Л. Кроль, О. Михайлова, О. Пуртова, Д. Шустерман); ментальність у ділових культурах (Г. Гофстеде, М. Бонд, Р. Льюїс, Дж. Моул, Д. Дюррей, Н. Андерсен, В. Пронніков, В. Цепцов), архетипи лідерства (К. Ходжкінсон). Теорію та практику формування управлінської культури фахівців представлено в роботах таких авторів, як В. Алфімов, Т. Базарова, Л. Балабанова, Ю. Богоявленська, Т. Грабар, Б. Ерьомін, Г. Зайцев, В. Колпаков, В. Кудін, Ю. Палех, Л. Ромашова, О. Ромашов, А. Урбанович, Є. Ходаківський та ін. Разом 3 тим аспект ментальних детермінант формування управлінської культури висвітлений недостатньо. 
Mema cmammi- на основі антропологічного підходу дослідити чинники формування управлінської культури.

Управлінська культура є складником загальної культури особистості і свідчить про відповідний спосіб соціального життя. Управлінську культуру можна віднести до спеціалізованого виду культури, що відповідає блоку культурних аспектів соціальної організації (політична, правова, господарська культура тощо). Під управлінською культурою ми розуміємо динамічне системне особистісне утворення, що охоплює цінності, спеціальні знання й уміння, особистісні якості, які забезпечують ефективність здійснення управлінської професійної діяльності в контексті забезпечення паритету суспільства та природи.

Аналізуючи витоки управлінської культури, Є. Ходаківський, Ю. Богоявленська, Т. Грабар уважають, що вона повинна розглядатися не тільки в аспекті знань загальної психології, психології особистості, психології творчості, соціальної психології, практичної психології, акмеології, вікової і педагогічної психології, психології кар'єри, психології праці, інженерної психології, економічної психології, психології бізнесу, а й етнопсихології [13, с. 8$]$.

А. Урбанович, вивчаючи витоки управлінської культури, акцентує на доцільності врахування менталітету як соціально-психологічного явища [11, с. 20].

Вивчаючи систему культурологічної підготовки фахівців аграрної галузі, Н. Костриця наголошує на необхідності застосування антропологічного підходу, що зумовлює розуміння цінності етносів, національних моделей осмислення культури, геокультурних вимірів духовного життя нації. Антропологічний підхід грунтується на етнічних особливостях кожного народу, на специфічних виявах буття нації. В антропологічному сенсі культура - це складна динамічна система національних цінностей. Етнокультурна компетентність має значний методологічний потенціал для відродження традицій сільськогосподарської праці в системі вищої аграрної освіти $[5$, с. $68,77,142,145]$.

У фокусі антропології для поняття «культура» актуальні такі аспекти: культурне становлення, або просвіта, суспільства й людини; сукупність і цілісність суспільних звичаїв, традицій; природна цілісність (система), яка протистоїть іншим культурним цінностям. Сутність антропологічного підходу полягає в осмисленні чужої та власної культур, у виявленні їх самобутності, розумінні відмінностей між традиціями, формуванні шанобливого ставлення до культурних феноменів [8, с. 8-9, 16].

У науковому дискурсі досі не вироблене чітке й усталене визначення ментальності; не встановлений їі визначальний вплив на результати індивідуальної і суспільної діяльності; не відпрацьовані механізми ії впливу на управлінську культуру.

Зокрема, Р. Додонов під ментальністю розуміє стиль світосприйняття, який відображає тривалий процес сумісного існування людей у єдиних природногеографічних і соціокультурих умовах. Ментальність виражається у побудові картини світу. Вона інтегрує хаотичний потік психічних образів і уявлень, характерних для духовних спільностей у процесі створення світогляду. Відповідно ментальність постає контекстом, на тлі якого розгортається унікальний спосіб бачення людиною змісту навколишнього середовища. До основних детермінант процесу виникнення i функціонування ментальності науковець відносить такі: природні (географічне розташування, клімат, рельєф, вода, наявність корисних копалин, багатство флори і фауни); соціального середовища (етнічне оточення, соціальна структура, війни, революції, реформи); внутрішні причини (ритми етнічного життя, інтенсивність інтерсуб' єктивних комунікацій, спілкування, спільна діяльність, освіта, виховання). 
У ментальність входять лише ті моменти мислення, які не викликають сумніву, підкріплені та багаторазово апробовані й доведені до автоматизму. Ментальність біологічним способом закріплює соціальні чинники, важливі для процесу адаптації людини в соціоприродному середовищі. «Для того, щоб та чи та реакція людини стала «ментальною», вона повинна пройти довгий шлях від багатократно повторюваного мислиннєвого і поведінкового прийому через його легітимізацію, через перетворення його в норму реакцій, в автоматично спрацьовуючий стереотип, у звичку свідомості, навіть у несвідоме - до спадково закріпленої інформації про «нормальне» для певного етносу світосприйняття» [2, с. 8, 66, 99].

В. Сніжко, підкреслюючи геопсихічний уплив біогеографічного та біоценозного середовища на сомато-психологічний стан людської психіки, природне довкілля вважає найважливішим чинником людиноформувальної геопсихологічної структури. Відповідно це призводить до певного розуміння i етнічної культури як сукупності матеріальних і духовних цінностей, що склалися еволюційним соціоприродним шляхом на геопсихічній території засобами етнічного самовизначення (особливої системи харчування, етноестетики, богорозуміння, праці) [9, с. 158, 197].

А. Фурман вважає ментальність духовно-уречевленим, культурно-психологічним феноменом, оскільки вона виражає колективне несвідоме, соціальний характер та індивідуальність етносу. Науковець наголошує на неусвідомленій природі ментальності, за якої програмні взірці поведінки реалізуються через психологічні механізми наслідування і мають критично неосмислений, нерефлексований етнічним загалом характер. При цьому ментальне ядро етносу знаходиться між двома рівнями філо- та онтогенетичного функціонування психіки (з одного боку, архетипи колективного несвідомого, а з іншого, соціально змінні форми суспільної свідомості). Відповідно ментальність розуміється як складний природно-соціальний продукт духовного життя нації, якість якого визначають такі показники: природні умови життя, традиції та усталені моделі поведінки етносу, соціальні інститути; культурні стратегії індивідуального розвитку та самореалізації етносу.

Отже, науковець наголошує на залежності структурування суспільної свідомості від унікальності культури суспільства. Саме культура є своєрідною матрицею, де формується та функціонує етнічний менталітет. Тому під менталітетом дослідник розуміє певну духовну субстанцію, що є похідною від національної культури, оскільки він реалізується на основі визначених програм суспільного життя [12, с. 18, 33-43].

На думку Ю. Мединської, етнічний менталітет - це «багатовимірна інформаційна психічна структура, що може бути детермінована як на генетичному рівні, так і без вузькобіологічної причинності і реалізується на основі та завдяки циркуляції інформаційних потоків (психічних змістів) різної значимості та міри впорядкованості, різної інтенсивності та ступеня усвідомленості, глибини причинонаслідкових та акаузальних зв'язків, котрі всі разом складаються в етнічну ідентичність» $[6$, с. 55].

О. Ковальов підкреслює в ментальності внутрішній (емоційний) аспект носія цінностей певної епохи, наголошуючи на його невідрефлексованій структурі, де карта світу не усвідомлюється, а сприймається на рівні асоціацій. Під ментальністю він розуміє «той рівень світоглядно-психологічних засад, який належить до царини «колективного безсвідомого», який становить невідрефлексовану частину 
суспільної свідомості, яка протистоїть системі раціональних знань, що не піддавалася форсованій трансформації» [3, с. 19-28].

На підставі аналізу характеристик менталітету можна прогнозувати соціальнополітичні та психологічні реакції людей на певні події в той чи той проміжок часу в конкретній країні або групі країн. Менталітет - це загальна сукупність політикопсихологічних характеристик у сфері поведінки або мислення певної соціальнополітичної чи етнічної спільноти людей [1, с. 7].

I. Старовойт розуміє під менталітетом «соціопсихологічний феномен, що характеризує етнічні спільноти й окремих представників етносу і визначає способи сприйняття та інтерпретації певною етнічною групою навколишнього світу, а також способи i форми практичного ставлення іï до природного i соціального середовища» $[10$, с. 13].

Це визначення ментальності візьмемо за вихідне, оскільки, на нашу думку, у ньому підкреслено три ознаки, які є важливими для нашого дослідження: по-перше, площина глибинних психологічних характеристик етносу, які регулюють його поведінку, рефлексію та спосіб сприйняття світу, осмислення і практичне ставлення до природи, соціуму і самих себе (автор називає це вихідною психологічною «матрицею», яка спрямовує ставлення індивіда до світу); по-друге, менталітет не вичерпується сферою свідомого, а передбачає у себе несвідомі, ірраціональні феномени індивідуальної і колективної психіки; по-третє, менталітет виникає як феномен життєдіяльності етносу, виводиться із історії народу, геополітичних, соціальних, культурних особливостей, але при цьому структури ментальності залишаються відносно незалежними від соціокультурних подій і ситуацій; почетверте, менталітет дає можливість прогнозувати соціально-політичні та психологічні реакції людей тощо.

Поряд із загальними трактуваннями поняття ментальності науковцями відстоюється ідея існування видової ментальності: господарська (Р. Додонов), трудова (Д. Богиня, В. Семікіна, І. Фурас), селянська (О. Ковальов, Ю. Присяжнюк) тощо.

Р. Додонов за родо-видовими ознаками розвиває ідею видової ментальності, а відтак «господарської ментальності». Кожна із видових ментальностей у своїй основі має спільну етноментальність, спадково закріплену 3 особливостями етнічного світосприйняття, поєднуючи як природно-біологічний, так і соціальні аспекти, що зумовлює іï стійкість і консерватизм. Дослідник зауважує, що господарські стереотипи й автоматизми виконують фіксацію найефективніших робочих прийомів, які були досягнуті попередніми поколіннями. Саме через ментальність відбувається процес удосконалення трудових навичок, які зберігаються навіть після зміни традиційних форм господарювання. Господарська ментальність - це закріплені в глибині психіки-свідомості і підсвідомості життєві стереотипи ведення господарства, розв'язання повсякденних проблем, які пройшли перевірку часом і стали побутовими нормами» [2, с. 65-66 ].

Д. Богиня, М. Семикіна, І. Фурас уважають, що трудова поведінка людини та результати праці значною мірою зумовлені менталітетом. Відповідно, під трудовим менталітетом розуміється соціально-економічна категорія, яка узагальнено відображає рівень національної трудової свідомості суспільства, соціальних груп та верств населення, окремих індивідів, сприйняття сенсу трудової діяльності, ціннісні орієнтації, інтереси, потреби, які зумовлюють спонукальні мотиви певної трудової поведінки [2, с. 57].

О. Ковальов зазначає, що категорія ментальності є спільною для всього людства, але водночас вона диференціюється. Це дає підстави виокремити ментальність 
селянства, яка залишилась сталою і незмінною, зберігаючи елементи світогляднопсихологічних парадигм минулого. Саме в селянській ментальності підкреслюється традиційність селянської культури, яка є споконвічно аграрною [2, с. 29].

Ю. Присяжнюк під ментальністю українських селян розуміє колективне несвідоме, притаманне для більшості українського хліборобського народу, що залишилося не прорефлексованим і логічно не виявленим. Історична самобутність українця полягає у тому, що він «довічний землероб». Історія не знає випадків, щоб на території України землеробство втрачало пріоритетність, відтак українське селянство завжди зберігало морально-психологічні та економічні зв'язки з землею: «українець (праукраїнець) міг бути вільним або залежним, міщанином або козаком, жити у національній державі або перебувати в колоніальній залежності, але завжди залишався хліборобом. I навіть коли втрачав власну державу, значною мірою вижив завдяки «сидінню на землі». У такий спосіб він зберігав себе не лише фізично, але й етнічно [7, с. 15].

Основними характеристиками ментальності селян $є$ такі:

- циклічність та нерівномірна завантаженість аграрної праці;

- пріоритет колективних видів діяльності;

- низький рівень спеціалізації за окремими професіями (працівник-універсал);

- низький рівень індивідуальних соціальних вимог людей;

- незначні відмінності між повсякденною культурою та спеціалізованими аграрними знаннями й уміннями тощо [4; 14, с. 88$]$.

Управлінська культура є складником загальної культури особистості і свідчить про відповідний спосіб соціального життя. Це динамічне системне особистісне утворення, що охоплює цінності, спеціальні знання й уміння, особистісні якості, які забезпечують ефективність здійснення управлінської професійної діяльності. Ментальність впливає на сомато-психологічний стан людської психіки. Вона визріває на тлі генетико-біогеографічного та біоценозного середовища та носить невідрефлексований етносом характер. Ментальність постає контекстом, на тлі якого розгортається унікальний спосіб бачення людиною змісту навколишнього середовища та свого місця в ньому. Це зумовлює необхідність врахування ментальності у формуванні управлінської культури фахівців сільськогосподарської галузі, тим самим створюючи умови для сприяння відродженню національної культури, національної економіки.

1. Богиня Д. П. Ментальний чинник у сфері праці: проблеми теорії та практики / Д. П. Богиня, М. В. Семикіна; передмова І. Ф. Кураса. - К. : Шторм, 2003. - 382 с. 2. Додонов Р. А. Теория ментальности: учение о детерминантах мыслительных автоматизмов / Роман Александрович Додонов. - Запорожье: p/a «Тандем-У». - 1999. - 264 с. З. Ковальов О.Л. Час у структурі традиційної ментальності (на матеріалах української етнології)/ Олександр Леонідович Ковальов. - Кіровоград: ПП «Центр оперативної поліграфії «Авангард», 2011. 168 с. 4. Коган Н. Л. Цель и смысл жизни человека / Н. Л. Коган. - М. : Мысль, 1984. - 252 с. 5. Костриця Н. М. Культурологічна підготовка майбутніх фахівців аграрної галузі: [монографія] / Н. М. Костриця. - Ніжин : Видавець ПП Лисенко М. М., 2012. - 400 с. 6. Мединська Ю. Я. Колективне несвідоме як глибинна детермінанта етнічного менталітету: автореф. дис. на здобуття наук. ступеня канд. психол. наук: спец. $19.00 .01 /$ Ю. Я. Мединська. - О., 2005. - 20 с. 7. Присяжнюк Ю. П. Українське селянство XIX-XX ст.: еволюція, ментальність, традиціоналізм: [навч. 
пос. для студ. іст. факультетів] / Юрій Петрович Присяжнюк. - Черкаси : Відлуння Плюс, 2002. - 120 с. 8. Розин В. М. Введение в культурологию / В. М. Розин. - М. : Междунар. пед. академия, 1994. - 104 с. 9. Сніжко В. В. Нариси 3 психоетнічної екології України / Валерій Володимирович Сніжко. - К. : Веселка, 2001. - 334 с. 10. Старовойт I. С. Збіг і своєрідність західноєвропейської і української ментальностей. Філософсько-історичний аналіз / Іван Сергійович Старовойт. Тернопіль: Діалог, 1997. - 256 с. 11. Урбанович А. А. Психология управления / А. А. Урбанович. - Мн. : Харвест, 2001. - 640 с. 12. Фурман А. В. Психокультура української ментальності / А. В. Фурман. - Тернопіль : НДІ МЕВО, 2011. - 168 с. 13. Ходаківський Є. I. Психологія управління/ Є. I. Ходаківський, Ю. В. Богоявленська, Т. П. Грабар. - К. : Центр учбової літератури, 2009. - 608 с. 14. Шейко В. М. Культура. Цивілізація. Глобалізація (кінець XIX - XX ст.): В 2 т. [монографія] / В. М. Шейко. - Х. : Основа, 2001. -Т. 2. - 400 с. 